\title{
THE 'WHITE ARMY OF TERROR': EUROPEAN CONVERTS TO ISLAM AND PUBLIC IMAGINATION
}

\author{
Monika Gabriela Bartoszewicz*
}

\begin{abstract}
This paper focuses on the representation of European converts to Islam in the public imagination. Firstly, the theoretical grounds for representations of converts in public imagination are identified and media images of converts involved in political violence are presented. The second part of the paper discusses the three prevailing motifs pertaining to European converts to Islam within the context of political violence. The Young and Angry, Swift and Deadly, and Gullible and/or Brainwashed motifs present in public imagination, and ubiquitous in the media and pop culture, are often mimicked in scholarly analyses. While these three images are not the only media representations of European converts to Islam, they are the most prevalent and thus indicate the main influences in shaping the public imagination. This paper accordingly elucidates how such conceptualisation leads to a false and misleading perception of the connection between European converts to Islam and terrorism.
\end{abstract}

Keywords: converts; Islam; media; stereotypes; public imagination; terrorism

\section{Introduction}

The specificity of the terrorist threat to Europe, with its home-grown, bottom-up dynamics, drew attention to European converts to Islam who are believed to be present in terrorist organisations in large numbers, where they occupy key positions and are considered to be assets of high operational value. The specificity of converts made them a particularly interesting object of public imagination both reflected and shaped by the media understood as printed and broadcasted information (i.e. newspapers and magazines, radio, TV and online media). These visions are fuelled and reinforced by media coverage, which furthers the spectre of 'the white army of terror'.

The cliché stipulates that, because converts want to prove themselves worthy of newfound faith, they are more prone towards radicalisation and fanaticism that know no national boundaries. ${ }^{1}$ This paper challenges the inflammatory, distorted and infused with disparaging stereotypes images implying that converts are the prodigal sons and daughters who went over to the 'dark side of the force' and allied themselves with the enemies who fight against everything the public holds dear. Trying to find an explanation for the tremendous success of stereotypes in shaping the public imagination, one needs to examine media influence over the people's common perception as well as their ability to project, repeat and spread images easily convertible to stereotypes. 
As Meili Steele points out, the difficulty with talking about public meanings from the outside derives from problems with developing a conception of public imagination, which would allow for bringing together contrasting approaches to the question of meaning. ${ }^{2}$ This paper follows her understanding of 'social imaginary' as "the images, plots, symbols, and background practices through which citizens imagine their lives". Thus, public imagination serves as a tool for recontextualising beliefs, concepts and images, enabling people's situations or phenomena, which are not amenable to replicating existing institutions of meaning. This definition is accepted because it avoids the tensions between the objectivity and subjectivity of shared dimensions when discussing political life, and it simultaneously transcends the mental landscape of an individual to reach out to the collective.

This paper is an attempt to map out the realm of public imagination regarding European converts to Islam. The previous research in this area was restricted to European Muslims ${ }^{3}$ or to minorities in general. ${ }^{4}$ The present paper builds on the previous studies. However it offers a refined analysis of European converts to Islam arguing that: a) there is a palpable shift from the ethnic to the cultural criterion and so, consequently, b) converts are portrayed as the 'other' or, as Saeed ${ }^{5}$ phrased it, 'the alien within', and c) projected into the sphere of public imagination in a limited repertoire of representations which can be grouped into three stereotypical images: Young and Angry, Swift and Deadly, and Gullible and/or Brainwashed. Such images are transferred to the public at large and taken seriously as a social fact. In order to develop this argument, it is necessary to examine the media coverage of European converts to Islam and identify common denominators of these repetitive narratives on which the storylines are built.

Popular images prevalent in the media, newspapers, books and films reinforced the stereotype of a convert as a somewhat disturbed individual posing a terrorist threat to the society and the state. Such seeds sown in the fertile ground of mass imagination produced a persuasive visualisation of an ineluctable danger posed by the converts. Thus, a topos was born and took root with its own dynamics and meaning, contributing to what Sheila T. Murphy described as a "perceptual baggage" of shared beliefs - in this case regarding the European converts to Islam. ${ }^{6}$ This stems from the simple logic stipulating that a set of uncomplicated assumptions will be easily translated into a potent image. A symbol transforming the often contradictory and confusing reality into an easy and digestible world that can be fixed and the problems, otherwise incomprehensible, solved according to the tangible, cognitive assumptions based on a worrying lack of knowledge and recognition. Simultaneously, the very same public imagination which shaped the picture of a European New Muslim (ENM) in a trivialised and demonised way became a basis for security policies and strategic analyses. 


\section{Images and Stereotypes}

Stereotypes, i.e. generalisations about social groups attributed to all the members without regard to variations existing among them, populate the media even though the researchers find these representations false. According to Gorham, stereotypical representations are important for two reasons: as agents conveying certain meaning and enabling action based upon it. ${ }^{7}$ Writing on the history of stereotyping, Sitaru noticed that the Western world inherited an assortment of stereotypes on Islam from the colonial period. ${ }^{8}$ These are deeply embedded in public imagination influencing and reinforcing pejorative perceptions through repetitive images and motifs. Seiter reminded that Walter Lippman, who coined the term 'stereotype' in his seminal book Public Opinion (1922), insisted that there is a clear link between public imagination and the stereotypes as the latter are simply pictures, i.e. images, employed by people to project and comprehend the reality. ${ }^{9}$

Myth and purposefully misleading information constitute the core of a stereotype building a simplistic, rigid and erroneous image based on discriminatory set of values. ${ }^{10}$ Seiter ${ }^{11}$ underlies that stereotypes have a descriptive aspect which can be accurate albeit selective as well as an evaluative component applied to justify social differences resulting in an image tainted by ideology. Repetition of stereotypes, concludes Seiter, in terms of narrative conventions is so ubiquitous because it provides the lowest common denominator for building storylines which in turn resonate with the public imagination. ${ }^{12}$ In order to become a stereotype, the given image needs to be reinforced and thus Graber concurs that it is very difficult to dispel the mythical images because they are so entrenched and incessantly repeated and because findings that contradict established orthodoxies are not well received by the public given the inherent resistance of stereotypes to information which contradicts them. ${ }^{13}$ In this context, Saeed argues further that the media representations focus on those who are the subject of public anxiety. ${ }^{14}$ This is reinforced by Bullock and Jafri, who in their analysis expose how the media shape who belongs and who does not belong to a given community (e.g. nation). ${ }^{15}$ Following the footsteps of their reasoning, I argue that European converts to Islam are seen and presented in the media as an implant of 'otherness' rather than being viewed as religious Europeans in their own unique way. Instead, converts are portrayed as outsiders, as the 'other', members of religion hostile to European values, espousing hatred, violence and gender oppression.

This is crucial since, as Murphy asserts, media portrayals not only may activate stereotypes, but also influence the subsequent judgments involving members of the stereotyped groups, and as such have a direct impact on the social as well as political reality around us. ${ }^{16}$ Ramasubramanian accentuates that people form 
stereotypes about others even with minimal or no direct contact with given social group. ${ }^{17}$ This ability to reach the public imagination via a 'cognitive shortcut' gives the media special consideration. The generative capacity of stereotypes, underlies Tarlo, incorporates the circulation of counter-stereotypes by groups, which are more likely 'othered' as well as influences the processes of selfstereotyping. ${ }^{18}$ Ramifications of this dual dynamics allowing the stereotypes to have an immense impact on communities are even more pronounced when we take into consideration the research by Burris and Jackson who claim that a devout religious commitment partially reflects individual's motivation to engage in religious self-stereotyping. ${ }^{19}$ By this token, if converts perceive themselves as exemplary religious group members and they absorb the media narratives shaping the realm of public imagination, they might be conditioned to align with the ubiquitous images presented by the media in spite of initial differences.

\section{Converts}

In reality, of the whole convert community, the overwhelming majority leads a peaceful existence and only a small fraction is radical. An even smaller number proceed to engage into terrorist activities. Edwin Bakker in his study, Jihadi Terrorists in Europe reports that there were fourteen converts to Islam (thirteen people with a Christian and one with a Hindu background) participating in terrorist attacks. ${ }^{20}$ While the situation has considerably changed with the growth of the Islamic State of Iraq and Levant, ${ }^{21}$ and then the establishment of the caliphate - a single state, transcending hitherto national borders based on the Qur'anic law of Shari'ah. ${ }^{22}$ In the many human rights abuses, massacres, acts of terrorism, including the execution of James Foley, and other forms of political violence widely covered by the global media about 3,000 fighters from the West are involved of whom many seem to be converts. ${ }^{23}$ In spite of being a minority, this small group of individuals has become emblematic, often taken as representative of the whole convert community projected onto the public imagination.

In this study I map out only the most repetitive images, clichés and stereotypes identified during my research bearing in mind that only recently has the interest in the whole convert community in Europe increased significantly. In public imagination conversion to Islam is most commonly explained in terms of "eccentricity, the insincere by-product of a marriage, the outcome of psychological crisis or disorder, social maladaption..." ${ }^{24}$ Those who speak about converts either perceive them as a danger to the secular state or focus on the religious and cultural 'otherness' of their identity. This is even more pronounced in the contemporary world, where security and strategic considerations have a central place. The public imagination stipulates that, after conversion, New Muslims want to prove their 
worth and sincerity of belief and thus become 'more Muslim than Muhammad', in turn becoming particularly vulnerable towards radicalisation. In the absence of any meaningful narratives from the converts themselves, proxy hypotheses are built on thin grounds of extrapolation. Extreme examples are projected as a norm and embedded within negative discourses. The troubled childhood/adolescence thesis is often invoked, like in the case of Vladimir Khodov, who was one of the six leaders in the 2004 Beslan school hostage crisis or Pascal Cruypennick, a white convert from Belgium, who was arrested on suspicion of sending suicide bombers to Iraq.

Cruypennick spent some time in prison, married and divorced an African woman and finally converted to Islam. As a Muslim, he pressed his girlfriend, a young Rwandan convert Angelique, to travel to Iraq on a suicide mission. Angelique did not yield and later gave an emotional interview on Belgian television explaining how Cruypennick tried to manipulate her. According to the media, unhappy childhood, trauma of physical abuse he had suffered from his father and subsequent divorce of his parents pushed him into the life of crime.

Similarly, Jerôme Courtailler and his younger brother David who came from a French Catholic petit-bourgeois family are presented as the sons of a respected butcher who, after his business failed, divorced his wife, and abandoned his family. The Courtailler brothers first turned to alcohol and drugs, and then converted to Islam. Jerôme moved to London, where he subsequently radicalised, travelled to Pakistan, and is now being held in Holland, suspected of an attempt to blow up the U.S embassy in France. ${ }^{25}$

Media coverage on Islam in general and on converts in particular focuses too much attention on sensationalised and/or violent events with frequently inaccurate or simplistic imagery, ignoring the nuances and allowing the stereotypes to develop in the audience's mind. It almost feels as if the same story is retold over and over again, with only a minor adjustment and small details, like the name or the country of origin amended here and there. The narrative shifts from the focus on ethnicity, to identity and culture. This is proved in a study by Sheridan, whose results suggest that religious affiliation might constitute a more powerful prejudice predicator than race or ethnicity which is exacerbated by feelings of fear and vulnerability and a perceived threat of the 'enemy within'. ${ }^{26}$ There are no major differences between Cruypennick, Khodov and Courtailler. In the precipice of public imaginary one can find the same elements just in different configurations: rebellious youth, influence of an impressionable older colleague, conversion and radicalisation with subsequent engagement in some sort of illegal activity. At the same time, the stories of converts presented in the popular discourse in spite of the deceiving depth and richness of details are devoid of any information that could contextualise political violence. 
Taking the topos of a violent convert out of context and infusing it with life independent of reality is, perhaps, most palpably observable in the case of Rakan Ben Williams. Ben Williams studied in a Western educational system, prayed in Christian churches and lived a Western life; he drank alcohol, lived promiscuously, and hated Muslims. But then, Ben Williams experienced an existential shift and secretly became a devoted Muslim adopting Al-Qaeda's aims and values. Hidden in Europe, undetectable, Rakan Ben Williams is 'the one who thirsts for the blood of the Crusaders, the secret soldier of Al-Qaeda,' gathering information and planning attacks and various Islamic websites presented his warnings as well as hunger for martyrdom. It would be terrifying if not for the fact that Rakan Ben Williams does not exist in reality - he is just a created figure, a media creation, stereotype of the model jihadi warrior who was born and raised in the West and now fighting against it meant to inspire other converts to follow his footsteps. ${ }^{27}$

Although the world of media is not a monolith, there are dominant and recurrent themes that prevail (positive exceptions notwithstanding) and thus a conceptual framework should be adopted. Imaginary patterns stem from mixing unrelated factors (e.g. gender and religion) and maintaining confusion through semantic relativity that orchestrates discursive conflicts of two different cultures whereby Islam is incompatible with democratic values as a religion of violence. The catalyst for the growth of such images is drawn by a negative discursive frame, which leaves a vast space for media manipulation and stereotyping. In public imagination, there are three main motifs regarding European converts to Islam within the context of political violence. Media, which feed the repository of images and visualisations, usually portray the converts as Young and Angry or Swift and Deadly. Occasionally, a third picture of a Gullible and/or Brainwashed convert resurfaces. Only very rarely the converts are presented in a different way, although invariably such stories are meant to show an 'exception to prove the rule.'

\section{Young and Angry}

The Young and Angry portrait grounds this study in a broader perspective of social reality beliefs. Media stories projecting this image into the public realm tie together identity, socio-economic cohesion and security issues, and associate converts with social conflict on the one hand, and with cultural disharmony on the other. There are several stories presenting young people as young idealists revolting against the established system. This is, perhaps, best seen among several French converts, including the Courtailler brothers David and Jerome, and Christopher Caze all of whom fought in Bosnia and were later involved in other jihadist activities. Christopher Caze, a 25 -year-old former medical student 
who travelled to Bosnia as a hospital medic and returned to France as a radical Islamist only to lead the so-called Roubaix Gang with links to GIA. In March 1996, when the leaders of the Group of Seven industrialised nations, including French President Jacques Chirac were to meet in Lille, near Roubaix, Caze's group filled a Peugeot with explosives and compressed gas, and parked it three blocks from the meeting site. French police defused the bomb and raided the group's hideout in Lille. Four of the terrorists were killed there and Caze, who managed to escape, was stopped the next day at a roadblock and shot during an attempt to ram his way through the blockade. In short, this motif accounts for a youthful rebellion expressed in religious terms. As Roy observed, "To convert to Islam today is a way for a European rebel to find a cause; it has little to do with theology," ${ }^{28}$ and thus converts are portrayed as revolutionaries, who are not involved in actual conflicts and instead feed off the imaginary perception of dissent.

The Young and Angry motif is also the favourite explanation for female radicalisation. It provides a repertoire of images potent enough to interpret the phenomenon of women-terrorists. In this context, the iconic image of Muriel Degauque, the first white female suicide bomber, epitomises the Young and Angry motif in public imagination. Muriel Degauque was born and brought up as Catholic in the small factory town of Monceau-sur-Sambre in Belgium. In spite of her working class background, she graduated from the best high school in the area. Her life changed diametrically after the tragic death of her brother, who was killed in a motorcycle accident: she started to drink heavily; became a drug user (although she was never arrested); and she sometimes ran away from home or was seen sleeping at the doorstep of a local community centre. In her early twenties Muriel moved out to Brussels and married a much older Turkish man, whom she subsequently divorced two years later, in 1990. Being a very pretty, blue-eyed blonde, she had several boyfriends, leading her mother to remark that she lost count of how many relationships her daughter had. ${ }^{29}$ In the late 1990s, Degauque met an Algerian man who introduced her to Islam, to which she converted (nonetheless, without forming any romantic relationship with him). Shortly after becoming Muslim, she met Issam Goris, who was seven years her junior, the son of a Belgian man and a Moroccan woman, and known to Belgian police as a radical Islamist. ${ }^{30}$ They got married in 2000 and moved to Morocco where Degauque learnt Arabic and studied the Qur'ran.

The couple returned to Belgium two years later; by then Degauque was no longer Muriel but Myriam. Media stories presented how new religion became the axis of her whole life and replaced everything that was there before. Migration to a foreign country followed by a social and cultural rupture only intensified the importance of Islam. Media representations formulated the same concerns 
regarding her lifestyle: Degauque was wearing not only a headscarf but a chador, i.e. a full length robe worn by Muslim women in North Africa. Eventually, she wore a burqa with gloves so no one could recognise her, not only the regular Belgians who did not suspect a white Belgian, but even her friends who had known her for a long time. ${ }^{31}$ Journalists targeted convert's social circles and reported that Degauque removed herself from all kinds of non-Islamic influence and with the exception of her parents, she socialised only with Muslims. Another theme explored by the media was the fact that not only did she conform to the strictest interpretations of Shari'ah, but also required other people, including non-Muslims, to follow them. For instance, when she and her husband were visiting her parents, she would eat separately from her father and forbid them to turn the TV on or to allow any alcoholic beverages to be consumed in the house. During interviews Mrs Degauque described her daughter as "more Muslim than Muslim," 32 and explained how the relations with her family suffered because parents remained sceptical towards Islamic lifestyle of their daughter. The family grew very distant, eventually to the degree that Degauque did not even visit her mother when she was hospitalised. Similarly, Mr And Mrs Degauque did not even know that their daughter left the country when in August 2005 Muriel called for the last time from Syria informing her parents she would be gone for more than a year. On 9 November 2005, at the age of 38, Degauque committed a suicide attack against American forces in Baquba, Iraq driving past a U.S. patrol and wounding one soldier, in what is believed to be the first European woman convert suicide mission which became a focal point of all the media stories. ${ }^{33}$

\section{Gullible and/or Brainwashed}

Prevalence of this motif in popular imagination was relatively short-lived and its proliferation proved to be inversely proportionate to the degree of terrorism's pervasiveness. In the past more than now converts were depicted as helpless individuals driven into the arms of religious group by "brainwashing" where groups mould new members through manipulation. It is worth mentioning though that the popular theory of brainwashing and coercive conversion is nonexistent among European converts to Islam and these theoretical explanations of submission to powerful manipulation and group forces ${ }^{34}$ are not present and therefore cannot be used to explain the phenomenon of converts' engagement in terrorism. Another variance of the Gullible and/or Brainwashed stereotype invokes an image of female convert lured to faith via marriage or romance. Several media stories purveyed images of Samantha Lewthwaite, the White Widow, involved in the terrorist attack in a Nairobi shopping mall, which killed more than 70 people $\mathrm{p}^{35}$ or Sally Jones (Umm Husain), a female British convert who travelled to Syria 
to join the Islamic State with her jihadi husband ${ }^{36}$ emphasising their naivety or opportunism.

Notwithstanding the reality, popular imagination feasts on the deathly potential of such a combustible concoction when a susceptible convert is preyed upon, radicalised and lured into terrorism. The Gullible and/or Brainwashed motif is best exemplified in the case of Mohammed Rasheed (Nicky Reilly), who in May 2008 was persuaded to attempt a suicide bomb attack in a restaurant in Exeter by British-based radicals. ${ }^{37}$ According to the media his actions and even his conversion are supposed to be manifestations of his vulnerability. The media reported that Reilly, a recent convert, stood out as the lone English convert in the Islamic Centre for Ply and Cornwall in the Mutley area where he attended prayers. ${ }^{38}$ In a statement released on the evening following the alleged attempted bombing, Deputy Chief Constable Tony Melville said: "Our investigations so far indicate Reilly, who has a history of mental illness, had adopted the Islamic faith. We believe, despite his weak and vulnerable state, he was preyed upon, radicalised and taken advantage of." This statement was constantly repeated and expanded on in all the media reports that followed. In the fertile ground of popular imagination the seed grew quickly and Reilly became the victim - a vulnerable individual who had been brainwashed and corrupted. Having been brainwashed, he cannot be held fully responsible for his own actions. So there is transference of responsibility for the alleged attempted bombing as his involvement in the attack was in some way involuntary.

This motif shows interestingly how in the public imagination conversion to Islam is causally linked to mental illness or other deficiencies rendering the convert unable to apprehend reality. Reilly's naivety is the main factor which removes responsibility not only for his involvement in the attempted bombing, but also for his conversion to Islam. This understanding is clearly visible in the comments from Reilly's neighbours, who claim that Reilly is "naïve and easily led" and "can't think for himself." 39 Furthermore, because Reilly is "mentally ill" with "the mental age of a ten-year-old," his actions, including his conversion to Islam, were not done of his own volition. To the contrary, in the discursive space of public imagination, Reilly was presented as an individual with mental health problems, who has been brainwashed into converting to Islam and was then radicalised, i.e. persuaded to carry out a terrorist attack..$^{40}$

In Reilly's case, the gullibility factor is encapsulated in his mental health problems. While all the public images presented Reilly as someone with "a history of mental illness" or "mentally disturbed," the details varied considerably. While some argued that Reilly was sectioned under the Mental Health Act, and had been in residential treatment, others acknowledged that the convert is a former mental patient, but instead of diagnosing him with schizophrenia, they argued 
that Reilly's psychiatric needs are rooted in the fact that he suffers from some other form of disability. The images differed slightly from Asperger's Syndrome to autism to an obsessive compulsive disorder. Furthermore, as if one factor was not strong enough to account for engagement in terrorist violence, other narratives presented Reilly as someone with a history of self-harm and several suicide attempts. According to these versions Reilly had a very low IQ, which not only caused learning difficulties, but also made him unable to exercise proper judgements. Again, in the plethora of public images the details varied: Reilly either self harmed by slashing his wrists or took an overdose when he was 16 only to stab himself in the stomach. Alternatively, his suicidal tendencies were accentuated. Similarly, the public imagination could not decide whether Reilly made only two apparent suicide bids or tried to commit suicide several times. The final reason why it was possible to brainwash Reilly into committing a terrorist attack is because the convert comes from a dysfunctional family.

Thus, the narratives suggest that Reilly should be seen nearly blameless as in the whole terrorist plot he was a manipulated puppet, while his conversion and his actions are merely manifestations of his vulnerability. These vulnerabilities rendered him inept and lacking life-skills and subsequently provided and easy prey for Islamic radicals. In public imagination, Reilly "obviously met up with the wrong people" and "was brainwashed into becoming a Muslim" masterminded the whole terrorist plot. While the case of a "Big Friendly Giant" 42 still remains somewhat exceptional, the aim of a Gullible and/or Brainwashed motif in public imagination is to highlight how vulnerable people are being taken advantage of by extremists.

\section{Swift and Deadly}

The Swift and Deadly motif is the most ubiquitous of all the media portraits of European converts to Islam present in public imagination. It preys upon the subconscious fear of terrorist attack that is impossible to predict and prevent, and in this sense the figure of a blonde, blue-eyed convert epitomises all the terrors. "I lived exactly the kind of life that every young person in the West wants to live. But I could not see any meaning," wrote Eric Breininger, also known as Abdul Gaffar El-Almani in his memoirs. ${ }^{43}$ Breininger is an author of Mein Weg nach Jannah (My Path to Jenna - Jenna meaning paradise in Arabic), an autobiography believed to be a genuine account of the German convert that was published after his death on one of the jihadist websites and served as a foundation for the media representations. The Swift and Deadly image provides the parameters of the media debate and the stories converts within a discourse directly referring to security issues. Representations follow the pattern of 
describing the departure from 'normal' to 'radical' or 'extremist.' For instance, media revelled on Breininger's pre-Islamic life of 'a typical western teenager,' which included frequenting parties and numerous relationships with girls. What was normal for him before the conversion, in hindsight became "following condemned Satan's way." ${ }^{4}$ Breininger's quest for the meaning of life took a new turn, when in his workplace he came into contact with a Muslim colleague who introduced him to Islam and took him to a local mosque. ${ }^{45}$ Breininger found the truth and sense his life was lacking; like a castaway who discovers a paradise island. Breininger converted and radicalised almost simultaneously, and his conviction that everyone must live their lives according to the values he professes, progressed incredibly fast.

The period of total withdrawal and swift transformation constitutes the second building block of media representations pertaining to the Swift and Deadly image. Media representations emphasise how converts fail to acknowledge the important and meaningful intermediate positions, hybrids and syncretism. To illustrate this point, they inform the public how after conversion Breininger devoted himself to the study of Islamic audio lectures and books. He quit school, stopped playing football, withdrew from his social circles and spent more time with new "brothers in Islam". ${ }^{46}$ The representations are securitised in terms of their impact on social harmony. Accordingly, they present how Breininger convinced his German girlfriend to convert and marry him under Islamic law. However, because it was not enough, he then demanded of his wife to stay at home, avoid going out and observe the strictest Salafi interpretations of Shari' ah. The woman refused to conform, as she converted only to please Breininger, not out of genuine conviction; they ended the relationship and Eric moved in with another convert, Daniel Martin Schneider, who in April 2007 was arrested as a prime suspect in the Ramstein Plot. A week before Schneider was arrested, Breininger left for Pakistan to obtain military training in one of the Islamic Jihad Union camps.

The third main component of the storylines focuses on hatred and violence. In a propaganda video released in 2008 and picked up by the media, especially in Germany, Breininger was seen armed and in fighter's gear. The audience could hear him confessing that he wants to die as a soldier of God. ${ }^{47}$ After his death the verbal claims were further reiterated by invoking his diaries where he wrote: "Hate of the kuffar [Arabic for "the infidels"] grew in me," and the implication is that he believed his choice to be the only option viable for every Muslim person: "Every Muslim should instil in themselves that one must live according to Allah's laws and that we need to rebuild an Islamic Nation." ${ }^{48}$ His theological deliberations and passages suffused with the pathos of a soldier of God were widely quoted. Simultaneously, the two continuous variables, the threat from 
within and the threat from without, were interacting powerfully to enhance the impression of imminent danger. In case of Breininger this referred to his calls to all Muslims, not only males, to join the mujahidin (fighters). The rationale behind it was the fact that many of the fighters wanted to start a family and Breininger insisted that terrorist camp is an ideal environment for raising children free from the harmful influences of the western societies. Thus, a vision of raising a 'white army of terror' was projected, especially that Breininger was allocated in the German Taliban Mujahidin group created in the first place for Germanspeaking Muslims who wanted to join jihad or, as Breininger described it: "to fulfil their duties to Allah and fight in the path of Allah to make Allah's word reign supreme. ${ }^{" 49}$ He was ecstatic to see the group steadily grow ${ }^{50}$ especially that the new group consisted of whole families with children making Breininger's dreams of new generation of mujahidin a reality. ${ }^{51}$ The final message, usually a direct transcript from Breininger's diary, was unequivocal:

With God's permission this offspring will become a special generation of terrorists that is not listed in any of the enemy's databases. They speak their enemy's languages, know their manners and customs and are able to mask and infiltrate the land of the kuffar [infidels] because of their appearance. There they will Insha'Allah be able to conduct one after another operation against Allah's enemies thereby sowing fear and terror in their hearts. ${ }^{52}$

\section{Conclusion and Recommendations}

My explorative research analyses the most frequent stereotypes shaping the public imagination by focusing on media images via discursive patterns concerning European converts to Islam. By examining various types of media narratives, it identified themes, topics and patterns grouping them into three most distinctive stereotypes regarding converts to Islam. The list is by no means exhaustive; to the contrary, exceptions or deviations occur. Nevertheless, it indicates the main influences in shaping the public imagination with regards to European New Muslims. $^{53}$

In an attempt to address theoretical blind spots, this paper offers the flavour of the three prevailing motifs present in public imagination pertaining to European converts to Islam within the context of political violence. By examining various types of media narratives, I pinned down themes, topics and frames grouping them into three most distinctive stereotypes: Young and Angry, Swift and Deadly, and Gullible and/or Brainwashed. Hence, three very persistent stereotypes inhabit the realm of public imagination and set out the agenda for public discussion 
framing how the audience should think and talk about European converts. What those three images have in common is the refusal to comply with the Western way of life, renouncing the shared values and the core beliefs constituting an alien element within the society. The power and impact of such stereotypes and their concrete consequences should not be underestimated. In the words of Emma Tarlo: "Much has been written about the power dynamics involved in the creation of dominant stereotypes and their oppressive effects as they collective imaginaries and become a basis for collective action." ${ }^{54}$

The first one, Young and Angry picture presents converts as disaffected and often troubled young people, who perceive the current wave of Islamic terrorism as the new revolution and join an idealist fight against the evils of the world, against the rich, the powerful, and the unjust. From this perspective, The Qur'ran appears as the new Das Kapital. The first motif renders the road from convert to jihadist remarkably short and simple and the terrorist potential is immense. In public imagination only because someone new to Islam does not have the cultural bearings or religious grounding sound enough to resist radical interpretations of Muslim faith. Consequently, it should be relatively easy to influence such person and, furthermore, it is believed that many young converts come with romanticised notions of the clash of ideas so typical for adolescents.

The second one presents converts as operational assets for the jihadist circles, whereby the instrumental value of European New Muslims is underlined not only in case of proselytising, logistics or support, but also for planning and carrying out terrorist attacks. Converts are portrayed as Swift and Deadly being the ultimate hidden enemy. The second picture partially explains why, in spite of the small numbers drawn to terrorism, the security services are stubbornly focusing on converts, and why they perceive them as a serious and growing terrorist threat. It furthermore coincides with a belief in coercive conversion and radical groups pressurising the newcomers into committing acts of political violence.

The third and final motif explains converts' terrorist activities with brainwashing and naivety. Murphy warns against a belief that, through an exposure to "disconfirming information," 55 which directly contradicts the prevailing stereotype it will be rendered obsolete and diminished is naïve. Atypically counter-stereotypic examples that are too exceptional or deviant either have no impact or provoke a 'boomerang effect' bolstering the stereotype instead of conquering it. If Murphy is correct, then the (rare) media stories conveying extremely positive convert images, do more harm than good. Furthermore, it needs to be observed that just like violence breeds violence, stereotypes breed stereotypes. Pointing towards strong negative stereotypes of Westerners among Muslims, Sitaru observes that the arising stereotypical imagery is interconnected and shapes parallel paradigms of self and other's 
perception while provision of complex information does not mean that certain images will lose credibility. ${ }^{56}$

Religious illiteracy of journalists identified by Wright might be one of the reasons for the media bias. ${ }^{57}$ Unfortunately, the motifs present in public imagination, ubiquitous in the media, pop culture and presented as social dogma are often mimicked in scholarly analyses, which leads to a false and misleading perception of the connection between European converts to Islam and terrorism. Popular images present converts as gullible individuals, easy to influence and prone to fall into an outbidding spiral when trying to prove their worth to the new brethren. The 'youthful anger' hypothesis is adjusted and presented rather as an 'outbidding spiral' with converts wanting to prove their true Muslimness and show without any doubts that in spite of being newcomers to religion they truly belong to the community of believers. Therefore, as opposed to the inchoate rage of a young person who is in general very impressionable, we have 'youngsters' in religious terms, who want to prove that as Europeans they left behind everything from where they came and everything that in their view the West stands for moral emptiness, hedonism, secularism, shallow consumerism and even a perception of a Western conspiracy against Muslims. What is more, they are swift and deadly as they never hesitate, possess an intimate knowledge of the enemy and are nearly impossible to intercept. In spite of the fact that some of these elements are true to a certain degree, it is necessary to point out that these are not present throughout all the cases of converted individuals. What in public imagination is presented as a rule, in reality proves to be rather an exception.

The paper suggests the following policy recommendations:

- There is a need for a proper conceptual framework for the media portrayal of 'others'. Muslims with the radical and extremist inclinations constitute a very small minority among the European converts and do not represent the entire population of the European converts to Islam. Therefore, media bias and prejudice in covering of Islam and Muslims should be rectified. All forms of ethnic and religious discriminations in the public space should also be restrained.

- Since the religious illiteracy of journalists is one of the main reasons for media misrepresentations of the European converts in media, the journalists are advised to enlighten themselves about Islam and its position on radicalism prior to writing on the subject.

- New converts to Islam are in need of the proper guidance in understanding the principles of Islam. Comprehension of the universal values of Islam such as moderation, mercy, justice, equality and respect toward all human beings may enable them to live more peacefully with themselves and their larger societies and functional lives. 
- In order to break the existing stereotypes, media could narrate more successful and encouraging stories of European converts and their contributions to humanity and their respective countries.

\section{Notes}

* Dr Monika Gabriela Bartoszewicz is the Head of Research in the Centre for the Thought of John Paul II in Warsaw, Poland. She can be contacted at mbartoszewicz@centrumjp2.pl.

1. M. Bloom, "Female Suicide Bombers: a Global Trend", Daedalus 136:1, (2007), 29-47.

2. M. Steele, Hiding from History: Politics and Public Imagination (New York: Cornell University Press, 2005), 5.

3. T. Modood, Ethnic Minorities in Britain: Diversity and Disadvantage (London: Policy, 1997); and A. Saeed, "Media, Racism and Islamophobia: The Representation of Islam and Muslims in the Media," Sociology Compass, vol. 1, no.2(2007), 443-462.

4. P. Hartman and C. Husband, Racism and the Mass Media (London: Dans-Poynter, 1974); T. Van Dijk, Racism and the Press (London: Sage, 1991); S. Cottle, Ethnic Minorities and the Media: Changing Cultural Boundaries (Buckingham: Open University Press, 2000); S. Cottle, Mediatized Conflict (Buckingham: Open University Press, 2006); C. Allen, "From Race to Religion: The New Face of Discrimination". In T. Abbas (Ed.), Muslim Britain: communities under pressure (London and New York: Zed Press, 2005), 24-47; E. Poole, Reporting Islam: Media Representations of British Muslims (London: I.B. Tauris, 2002); E. Poole and J. Richardson (Eds.) Muslims and the News Media (London: I.B. Tauris, 2006); B. Zelizer and A. Stuart (Eds.) Journalism after 9/11, (London: Routledge, 2002).

5. A. Saeed, "Media, Racism and Islamophobia," 451.

6. S.T. Murphy, "The Impact of Factual versus Fictional Media Portrayals on cultural Stereotypes", Annals of the American Academy of Political and Social Sciences 560 (November, 1998), 165-178.

7. B. W. Gorham, "Stereotypes in the Media: So What?", Howard Journal of Communications, 10:4 (1999), 229-247.

8. L. Sitaru, "Stereotypes about Islam and media commentators' discourse after 9/11", Romano-Arabica 12 (2012), 235-260.

9. E. Seiter, "Stereotypes and the Media: A Re-evaluation", Journal of Communication, 36:2, (Spring 1986), 14-26.

10. L. Sitaru, "Stereotypes about Islam," 239.

11. E. Seiter, "Stereotypes and the Media," 16, 21.

12. Ibid., 20.

13. D. Graber, "The Media and Democracy: Beyond Myths and Stereotypes," Annual Review of Political Science, no. 6 (2003), 39-160.

14. A. Saeed, "Media, Racism and Islamophobia," 443.

15. K.H. Bullock and G.J. Jafri, "Media (Mis) Representations: Muslim Women in 
the Canadian Nation," Canadian Women Studies, vol. 20, no. 2 (2000), 35-40.

16. S.T. Murphy, "The Impact of Factual versus Fictional Media Portrayals," 165.

17. S. Ramasubramanian, "Media-based Strategies to Reduce Racial Stereotypes Activated by News Stories," Journalism \& Mass Communication Quarterly, no. 84 (2007), 249-264.

18. E. Tarlo, "Reconsidering Stereotypes: Anthropological Reflections on the Jilbab", Anthropology Today, vol. 21, no. 6 (December 2005), 13-17.

19. C.T. Burris and L.M. Jackson, "Social Identity and the True Believer: Responses to Threatened Self-stereotypes Among the Intrinsically Religious," British Journal of Social Psychology, no. 39 (2000), 257-278.

20. E. Bakker, Jihadi terrorists in Europe: Their characteristics and the circumstances in which they joined the jihad. An exploratory study (The Hague: Clingendael Security and Conflict Programme, 2006), 69-85.

21. "The Evolution of the Islamic State in Iraq and the Levant," Stratfor (June 20, 2014).Retrieved from: <http://www.stratfor.com/video/evolution-islamic-stateiraq-and-levant\#axzz3C43d5Cr7> (accessed 20 June 2014).

22. Council on Foreign Relations, "Islamic State in Iraq and Syria," Council on Foreign Relations (August 08, 2014), <http://www.cfr.org/iraq/islamic-stateiraq-syria/p14811> (accessed 8 August, 2014).

23. "Why and How Westerners Go Fight to Syria and Iraq," The Economist (August 30, 2014), <http://www.economist.com/news/middle-east-and-africa/21614226why-and-how-westerners-go-fight-syria-and-iraq-it-aint-half-hot-here-mum> (accessed 30 August 2014).

24. See J. Birt, "Building New Medinas In These Scattered Isles," <http:// theamericanmuslim.org/tam.php/features/print/building_new_medinas_in_ these_sceptered_isles> (accessed 20 May 2011).

25. A. Barnett, "UK Student's 'Key Terror Role,"' The Guardian (October 18, 2001), <http://observer.guardian.co.uk/waronterrorism/story/0,,582225,00. html $>$ (accessed 25 May 2011).

26. L. P. Sheridan, "Islamophobia Pre- and Post-September 11 th 2001," Journal of Interpersonal Violence, vol. 21, no. 3 (March 2006), 317-336.

27. "The next Al-Qaeda soldier," Al Farouq (November 24, 2005), <http://www. al-farouq.com/vb/showthread.php?t=3769> (accessed 27 May, 2011); and M. Malkin, "Who Is Rakan Ben Williams?" Michelle Malkin (March 12, 2006), $<$ http://michellemalkin.com/2006/03/12/who-is-rakan-ben-williams $>$ (accessed 27 May, 2011).

28. O. Roy, "Al Qaeda in the West as Youth Movement: The Power of Narrative," CEPS Policy Brief No. 168 (2008).

29. T.A. Browne, and R. Watson, "The Girl Who Went From Baker's Assistant to Baghdad Bomber," The Times (December 2, 2005), <http://www.timesonline. co.uk/article/0,,7374-1900483,00.html $>$ (accessed 25 May 2011).

30. C.S. Smith, "Raised as a Catholic, She Died as a Muslim Bomber," New York Times (December 6, 2005), <http://www.nytimes.com/2005/12/06/international/ europe/06brussels.html?pagewanted=all $>$ (accessed 25 May 2011).

31. F. Tihon, "Making of Muriel the suicide bomber," The Sunday Times (December 4, 2005), 3.

32. "Journey of Belgian Female 'Bomber," BBC News (December 2, 2005), <http:// 
news.bbc.co.uk/2/hi/europe/4491334.stm> (accessed 25 May, 2011); and "Belgian Woman Bomber Identified. Belgian 'Suicide Bomber' Is Named," BBC News (December 2, 2005), <http://news.bbc.co.uk/2/hi/europe/4488642.stm> (accessed 25 May 2011).

33. N. Watt, "From Belgian Cul-de-sac to Suicide Bomber in Iraq," The Guardian (December 2, 2005), <http://www.guardian.co.uk/world/2005/dec/02/iraq. islam> (accessed 25 May 2011).

34. R.A.Straus, "Religious Conversionas a PersonalandCollectiveAccomplishment," Sociological Analysis, vol. 40, no. 2 (1979), 158-165; and T.E. Long and J.K. Hadden, "Religious Conversion and the Concept of Socialization: Integrating the Brainwashing and Drift Models," Journal for the Scientific Study of Religion, vol. 22, no. 1 (1983), 1-14.

35. See R. Evans, "The White Widow's 'Jihadi children'," The Daily Mail (October 4, 2013), <http://www.dailymail.co.uk/news/article-2444552/White-WidowSamantha-Lewthwaite-raising-Jihadi-children-murder-Islams-enemies.html> (accessed 04 October 2013); and "White Widow Samatha Lewthwaite's Love Poem to Osama Bin Laden Found on Computer During Police Raid," Mirror Online (October 22, 2913), <http://www.mirror.co.uk/news/uk-news/whitewidow-samatha-lewthwaites-love-2479295\#ixzz2jmBq6vkz> (accessed 22 October 2013).

36. C. Greenwood, "Revealed: Benefits Mother-of-two from Kent Once in All-girl Rock Band Who is Now Jihadi in Syria - and Wants to 'Behead Christians with a Blunt Knife'," The Daily Mail (August 31, 2014),<http://www.dailymail.co.uk/ news/article-2739006/Revealed-How-middle-aged-mother-two-Kent-used-girlrock-band-reinvented-jihadi-threatening-behead-Christians-blunt-knife.html> (accessed 31 August 2014).

37. A. Fresco, "Nicky Reilly, Muslim Convert, Jailed For 18 Years for Exeter Bomb Attack," The Times (January 31, 2009), <http:/can.politics.narkive.com/ GaSQrg3Y/muslim-converts-are-generally-ignorant> (accessed 31 August 2014).

38. M. Seamark and C. Fernandez, "Face of the 'Nail Bomber': Police Were Tailing Muslim Convert Before Restaurant Attack," The Daily Mail (May 23, 2008), $<$ http://www.dailymail.co.uk/news/article-1021502/Face-nail-bomber-Policetailing-Muslim-convert-restaurant-attack.html $>$ (accessed 31 August 2014).

39. A. Mostrous, "Recent Convert to Islam is Arrested After Bomb Explosion at Restaurant," The Times (May 23, 2008), 13.

40. J. Macintyre, "Exeter Bombing Suspect Was 'Brainwashed', Friends Insist,", The Independent (May 24, 2008), <http://www.independent.co.uk/news/uk/ crime/exeter-bombing-suspect-was-brainwashed-friends-insist-833571.html> (accessed 30 May 2014).

41. Ibid.

42. "Big Friendly Giant" was Nicky Reilly's nickname in the neighbourhood. See, R. Savill and A. Bloxham, "White Muslim Convert Bomb Suspect Named," The Telegraph (May 22, 2008), <http://www.telegraph.co.uk/news/uknews/2010241/ Exeter-bomb-Nicky-Reilly-white-Muslim-convert-is-named-as-suspect-inGiraffe-restaurant-explosion.html> (accessed 25 August 2014).

43. A.G. El-Almani (Eric Breininger), Mein Weg nach Jannah (Elif Medya, 2010). 
44. Ibid., 6 .

45. "Eric Breininger," Global Jihad (2011), <http://www.globaljihad.net/view page.asp?id $=1198>($ accessed 27 May 2011).

46. F. Schneider, E. Koch, M. Wichmann and K. Feldhaus, "What Does Eric Breininger Have Planned for Germany?," Bild (March 3, 2009), <http:// www.bild.de/news/bild-english/news/into-germany-but-what-does-he-haveplanned-5944284.bild.html> (accessed 27 May 2011).

47. Y. Musharbash, "Eric Breininger's Death: The Memoirs of a German Jihadist," Spiegel Online (May 5, 2010), <http://www.spiegel.de/international/germany/ eric-breininger-s-death-the-memoirs-of-a-german-jihadist-a-693216.html> (accessed 25 May 2011).

48. A.G. El-Almani, Mein Weg nach Jannah, 53.

49. "German Jihadists in Waziristan: Background," The Middle East Media Research Institute Report (October 8, 2010), <http://www.memri.org/report/en/print4658. htm $>$ (accessed 14 February 2012).

50. Y. Musharbash, "German Jihadist Eric Breininger Killed in Pakistan, Group Claims," Der Spiegel (March 5, 2010), <http://www.spiegel.de/international/ world/homegrown-terrorists-german-jihadist-eric-breininger-killed-in-pakistangroup-claims-a-692673.html> (accessed 04February 2012).

51. Y. Musharbash, M. Rosenbach, and H. Stark, "The Third Generation German Jihad Colonies Sprout Up in Waziristan," Spiegel Online (May 4, 2010), <http:// www.spiegel.de/international/germany/the-third-generation-german-jihadcolonies-sprout-up-in-waziristan-a-687306.html> (accessed 04 February 2012).

52. A.G. El-Almani, Mein Weg nach Jannah, 104.

53. See, "Essex Boys Sign Up for 'Holy War'," The Observer (February 24, 2002), $<$ http://www.theguardian.com/uk/2002/feb/24/religion.september11> (accessed 30 May 2014); "Europe Fears Threat From Its Converts to Islam," The New York Times via The International Herald Tribune, USA (July 19, 2004), <http:// www.religionnewsblog.com/7916/europe-fears-threat-from-its-convertsto-islam> (accessed 04 March 2009); "Al-Qaeda's White Army of Terror," Scotland on Sunday (January 13, 2008); S. Rayment, "Whites Being Lured Into Islamic Terror," The Telegraph (July 02, 2006), <http://www.telegraph. co.uk/news/uknews/1522878/Whites-being-lured-into-Islamic-terror.html > (accessed 30 May 2014); and K. Brice, "Media Representations of the White British Convert to Islam: harmless eccentric or threat to society?," Centre for Migration Policy Research, Swansea University (2011), <http://www.docstoc. com/docs/26477506/Media-Representations-of-the-White-British-Convert-toIslam> (accessed 30 May 2012).

54. E. Tarlo, Reconsidering Stereotypes, 14.

55. S.T. Murphy, The Impact of Factual versus Fictional,167 and 175.

56. L. Sitaru, Stereotypes about Islam, 239.

57. S.A. Wright, "Media Coverage of Unconventional Religion: Any "Good News" for Minority Faiths?," Review of Religious Research, vol. 39, no. 2 (December 1997), 101-115. 